\title{
ПРИНЦИП РОЗУМНИХ СТРОКІВ У ЦИВІЛЬНОМУ СУДОЧИНСТВІ
}

\author{
Дяченко С. В., Зборовська Н. О.
}

\begin{abstract}
У статmі здійснюється дослідження принципу розумних строків розгляду справи судом, його законодавче закріплення. Аналізується нормативно-правове закріплення принципу розумних строків як одного з принципів цивільного процесу в Конституції України та Цивільному процесуальному кодексі України. Проаналізовано думку таких вчених, як Р.О. Стефанчук, О.В. Рожнов. Розглядається судова практика застосування розумних строків та прецедентного права Європейським судом з прав людини.

Ключові слова: принцип розумних строків, судова справа, Цивільний процесуальний кодекс України, Конституція України, постанова пленуму Вищого спеціалізованого суду України.
\end{abstract}

В статье осуществляется исследование принципа разумных сроков рассмотрения дела судом, его законодательное закрепление. Анализируется нормативно-правовое закрепление принципа разумных сроков как одного из принципов гражданского процесса в Конституции Украинь и Гражданском процессуальном кодексе Украины. Проа нализированы мнения таких ученых, как Р.О. Стефанчук, О.В. Рожнов. Рассматривается судебная практика применения разумных сроков и прецедентного права Европейским судом по правам человека.

Ключевые слова: принцип разумных сроков, судебное дело, Гражданский процессуальный кодекс Украины, Конституция Украины, постановление пленума Высшего специализированного суда Украины.

The article deals with the principle of reasonable terms, their legislative fixing. This paper analyzes the concept of the principle of reasonable terms as one of the principles of the civil process. Case law on reasonable time limits is reviewed. The article analyzes the opinion of such scientists as Stefanchuk, Rozhnov. In order to determine the "reasonableness of the time limit", the first step is to establish a clear timeframe for the duration of the proceedings, the determination of which is more difficult in civil proceedings, since it ends with the enforcement of a decision of a national court. In order to ensure that the term of the case is consistent with the criteria of reasonableness, the judge in the case should consider harmony in ensuring: 1) prompt protection of violated, unrecognized or disputed rights; 2) committing to the litigants actions which are binding in the civil procedural law, which are necessary in the judge's opinion and are appropriate for the conviction of other litigants. The terms of exercising civil rights have the following features: 1) they are varied both in the sphere of influence on public relations and in the way of fixation and application; 2) act as a guarantee of timely implementation and realization by the participants of civil legal relations of the rights granted to them; 3) require a clear definition in the general rules of civil law (depending on the type of term) and the establishment of common mechanisms for their application. The terms of protection of civil rights are the terms of claim, the term of operative defense, limitation period and procedural time. This paper analyzes the legislative consolidation of the principle of reasonable time in the Constitution of Ukraine and the Civil Procedure Code

Дяченко С. В., Зборовська Н. О., 2019 of Ukraine. The article also examines the case law of the European Court of Human Rights. Such as the "Milassi v. Italy" case, the "Hnitsevich v. Ukraine" case, the "Khurava v. Ukraine" case, and the "Dulsky and others v. Ukraine" case.

Key words: principle of reasonable terms, court case, Civil Procedure Code of Ukraine, Constitution of Ukraine, resolution of the Plenum of the Higher Specialized Court of Ukraine.

Постановка проблеми та її актуальність. Вирішення питання забезпечення прав і свобод людини та громадянина сьогодні $\epsilon$ одним із пріоритетних завдань внутрішньої та зовнішньої політики усіх держав світової спільноти. Диференційований підхід до строків розгляду цивільних справ залежно від категорії, складності й навіть ціни позову обговорюється в цивілістичному процесі протягом багатьох десятиліть. Справедливість правосуддя, в тому числі цивільного, зумовлюється багатьма засадами, зокрема i розумністю строків.

Аналіз останніх досліджень i публікацій. Питання правового регулювання принципу розумних строків досліджували такі науковці: Р.О. Стефанчук, О.В. Рожнов, Ю.В. Навроцька, Ю.В. Христова, Л.Д. Білик, Н.В. Неледва, А.А. Горошко, В.А. Михайлик, Ю.А. Тобота, Г. Марунич, А. Колос, В. Солдатський, О.О. Рибак, В.В. Буга, В.В. Заборовський, С.О. Короєд, І.В.Турчин-Кукаріна та ін.

Мета. Завданнями статті $\epsilon$ визначення поняття розумних строків, дослідження нормативно-правового закріплення принципу розумних строків, а також аналіз судової практики із застосуванням розумних строків.

Виклад основного матеріалу. Завданням цивільного судочинства $\epsilon$ справедливий, неупереджений та своєчасний розгляд і вирішення цивільних справ 3 метою ефективного захисту порушених, невизнаних або оскаржуваних прав, свобод чи інтересів фізичних осіб, прав та інтересів юридичних осіб, інтересів держави [1, п. 1 ст. 2]. Саме своєчасний захист прав, свобод та інтересів осіб, що беруть участь у справі, $\epsilon$ одним із найважливіших факторів, що визначає доступність правосуддя та ефективність його здійснення.

Конвенція про захист прав людини та основоположних свобод, яка згідно з частиною першою статті 9 Конституції України $є$ частиною національного законодавства України, в пункті 1 статті 6 зазначає, що кожен при вирішенні питання щодо його цивільних прав та обов'язків має право на розгляд його справи протягом розумного строку [2]. Крім того, Європейська хартія про закон «Про статус суддів» також в п. 1.6 зазначає, що держава зобов'язана забезпечити суддів засобами для належного виконання ними своїх задач, в тому числі й для розгляду справ протягом розумних строків [3].

Цивільний процесуальний кодекс України (далі - ЦПК України) у п. 1 ст. 210 закріпив, що суд має розпочати розгляд справи по суті не пізніше ніж через шістдесят днів з дня відкриття провадження у справі. У п. 2 цієї ж статті зазначається, що суд розглядає справу по суті 
протягом тридцяти днів з дня початку розгляду справи по суті [1]. Тобто положення п. 1 ст. 6 Конвенції були імплементовані в правову систему України.

Строки в цивільному процесі відіграють важливу роль не лише в контексті своєчасного здійснення судочинства з мінімальними втратами часу, але й, на нашу думку, $є$ визначальними категоріями при забезпеченні гарантій здійснення суб'єктами цивільних процесуальних відносин суб'єктивних процесуальних прав і при виконанні покладених на них цивільних процесуальних обов'язків. $€$ вкрай важливим однакове розуміння суті і значення процесуальних строків.

ЦПК України не містить нормативного визначення поняття «процесуальні строки». Однак, встановлюючи в ст. 67 ЦПК види процесуальних строків, законодавець в загальному вигляді визначив їх як строки, встановлені законом, а якщо вони не визначені законом, то встановлені судом. У межах таких строків вчиняються процесуальні дії [1].

Р.О. Стефанчук під цивільним процесуальним строком розуміє «встановлений законом або судом період часу, впродовж якого може або повинна бути здійснена певна процесуальна дія учасником цивільного процесу» [4, с. 85]. О.В. Рожнов вважає, що процесуальний строк становить проміжок часу, визначений законом чи судом для вчинення процесуальних дій сторонами, іншими особами, які беруть участь у розгляді справи [5, с. 45].

Невизначеність поняття «розумний строк» судового розгляду призвела до того, що 25.01.2006 року Верховним Судом України був ухвалений лист № 1-5/45 «Щодо перевищення розумних строків розгляду справ», в якому були визначені лише дії, які окреслюють початок та закінчення проміжку часу, що підлягає оцінці на предмет його розумності з врахуванням критеріїв, вироблених в практиці Європейського суду з прав людини [7].

Враховуючи особливості, які виділяються в науці цивільного процесуального права при характеристиці правових аксіом, можна охарактеризувати правову аксіому розумного строку судового розгляду. По-перше, вона $\epsilon$ загальним орієнтиром для кожного судді під час розгляду та вирішення цивільної справи, тобто суддя має намагатися розглянути справу у найкоротші строки, не допускаючи поведінки, яка може бути оцінена як така, що призвела до затягування розгляду справи. По-друге, необхідність розгляду справи у розумні строки $\epsilon$ незаперечною, тобто іï не можна спростувати, оскільки, як вже зазначалося, кожна держава, яка ратифікувала Конвенцію, взяла на себе зобов'язання забезпечити права, закріплені в ній. По-третє, розумні строки судового розгляду існують паралельно зі службовими строками, закріпленими на рівні чинного законодавства, тобто паралельно з процесуальними нормами, в яких вказуються проміжки часу, протягом яких суд зобов'язаний вирішити справу. Вони визначають належні часові виміри цивільного процесу. По-четверте, розумні строки судового розгляду закріплені в п. 1 ст. 6 Конвенції й сприяють забезпеченню справедливості судового розгляду, досягненню доступності правосуддя. По-п'яте, для розумних строків судового розгляду притаманний самостійний зміст, відмінний від змісту службових строків, що вироблений прецедентною практикою Європейського суду з прав людини та становить ідеальну часову модель відправлення справедливого правосуддя.
Згідно зі статтею 129 Конституції України на національному рівні розумні строки розгляду справи судом $\epsilon$ однією із основних засад судочинства [2]. Право на розумні строки розгляду справи закріплюється у низці нормативно-правових актів України, зокрема ЦПК України, Кримінальному процесуальному кодексі України (далі - КПК України), Кодексі адміністративного судочинства України (далі - КАС України) тощо. Дублюється воно і у постанові пленуму Вищого спеціалізованого суду України (далі - ВСС України) з розгляду цивільних та кримінальних справ від 17.10.2014 р. № 11 «Про деякі питання дотримання розумних строків розгляду судами цивільних, кримінальних справ і справ про адміністративні правопорушення» [8].

Відповідно до ч. 1 ст. 157 цПК України суд розглядає справи протягом розумного строку, але не більше двох місяців з дня відкриття провадження у справі, а справи про поновлення на роботі, про стягнення аліментів - одного місяця [1]. У КАС України зазначено, що адміністративна справа має бути розглянута і вирішена протягом розумного строку, але не більше місяця з дня відкриття провадження у справі (ч. 1 ст. 122). Також у КПК України визначено, що судовий розгляд має бути проведений і завершений протягом розумного строку (ч. 1 ст. 318). Як видно із наведених норм, деякі з процесуальних кодексів встановлюють граничний строк, протягом якого справа має бути розглянута (ЦПК України, КАС України ), а деякі - ні (КПК України).

Принцип повноти і своєчасності виконання рішення був закріплений в новому Законі України «Про виконавче провадження» від 02.06.2016 р. Це принцип розумності строків виконавчого провадження. Однак сутність цього принципу суттєво відрізняється від того, що випливає зі старого законодавства. У чинному Законі не був закріплений конкретний строк, протягом якого виконавець зобов'язаний провести процесуальні дії із примусового виконання рішення, тобто строк здійснення виконавчого провадження. Стаття 13 « Сроки прийняття рішень виконавцями та вчинення виконавчих дій» нового Закону присвячена різним видам строків у виконавчому провадженні [9].

У постанові пленуму ВСС України з розгляду цивільних і кримінальних справ «Про деякі питання дотримання розумних строків розгляду судами цивільних, кримінальних справ і справ про адміністративні правопорушення» визначається, що вважається розумним строком у контексті судового розгляду справи: «Розумним, зокрема, вважається строк, що є об'єктивно необхідним для виконання процесуальних дій, прийняття процесуальних рішень та розгляду і вирішення справи з метою забезпечення своєчасного (без невиправданих зволікань) судового захисту» [8].

3 аналізу практики ЄСПЛ щодо тлумачення поняття «розумний строк» випливає, що строк, який можна визначити розумним, не може бути однаковим для всіх справ. Було б помилкою встановлювати один строк у конкретному цифровому виразі для усіх випадків. У кожній справі виникає проблема оцінки розумності строку, яка залежить від певних критеріїв, вироблених практикою ЄСПЛ. Цими критеріями $\epsilon$ складність справи, поведінка заявника, поведінка державних органів, значущість питання для заявника. У цПК України закріплене поняття «зловживання процесуальними правами». Законодавець передбачив обставини, які 
можуть розцінюватися як зловживання, затягування справи (подання безпідставних позовів, подання кількох позовів до одного відповідача з аналогічними даними, оскарження рішення, яке не підлягає оскарженню).

Юристи-практики дискутують щодо визначення зловживаннями процесуальним правом подання безпідставного позову, подання завідомо безпідставного позову, подання позову, який має штучний характер, а також подання завідомо безпідставного відводу. Вчені-цивілісти вважають сумнівною санкцію, передбачену ч. 3 ст. 44 ЦПК, яка закріплює можливість суду залишити заяву, скаргу або клопотання без розгляду у разі визнання їх зловживаннями процесуальними правами [12].

Так, у справі «Федіна проти України» від 2 вересня 2010 р. ЄСПЛ відзначив, що розумність тривалості провадження повинна оцінюватись у контексті обставин справи та з урахуванням таких критеріїв, як складність справи, поведінка заявника та відповідних державних органів. До того ж у справах «Дульський проти України» від 1 червня 2006 року та «Хурава проти України» від 08 квітня 2010 року ЄСПЛ звернув увагу на такий критерій, як значущість для заявника.

Одним із прикладів, коли поведінка заявників стала однією з причин тривалого розгляду спору, стало рішення у справі «Чірікоста і Віола проти Італії», де п'ятнадцятирічний строк розгляду був визнаний виправданим, оскільки самі заявники 17 разів зверталися з проханням про відстрочення процесу і не заперечували проти перенесень розгляду, здійснених на підставі заяви іншої сторони у справі [10]. В Україні досить поширеними $є$ випадки, коли особи, належним чином проінформовані про час та місце судового засідання, не 3'являються без поважної причини, не додають витребувані судом документи, тим самим призводять до тривалого розгляду справи.

Поведінка державних органів найчастіше призводить до затягування справи. Відповідно до рішень Європейського суду у справах «Войтенко проти України» (рішення ЄСПЛвід 29.06.2004 р.), «ПаскалпротиУкраїни» (рішення ЄСПЛ від 15.09.2011р.), «Буров проти України» (рішення ЄСПЛ від 17.03.2011 р.), «Коробов проти України» (рішення ЄСПЛ від 21.07.2012р.), «Іззетов проти України» (рішення ЄСПЛ від 12.01.2012р.), «Тодоров проти України» (рішення ЄСПЛ від 12.01.2012р.), «Балицький проти України» (рішення ЄСПЛ від 02.11.2011р.) [11] саме державні органи несуть відповідальність за порушення ст. 6 Конвенції. При цьому причини порушення можуть бути різними. Так, у справі «Войтенко проти України» Уряд визнав необхідність виконання рішення, винесеного на користь заявника, але зазначив, що рішення залишалось невиконаним через відсутність бюджетних коштів та законодавчих заходів. У справі «Гніцевич проти України» рішення, постановлене на користь заявника, залишалось невиконаним протягом семи років і восьми місяців.

Причинами порушення строків судового розгляду може бути порушення строків відкриття провадження, призначення i проведення судового засідання, призначення справи до розгляду, безпідставні численні відкладання розгляду справи, порушення строків виконання судових рішень, перерви в судових засіданнях, затримки з вини канцелярії суду або адміністративних органів тощо. У деяких випадках затримки викликаються перевантаженням судової системи. Так, у п. 18 рішення у справі «Міласі проти Італії» (1987р). Суд наголосив: «Конвенція наклала на договірні сторони зобов'язання організувати свої правові системи таким чином, щоб дати можливість судам реалізувати ст. 6 Конвенції». Іноді затримки, спричинені державними органами, можуть бути виправдані. Так, у вищезазначеному рішенні Суд зауважив, що держава не відповідає за затримку розгляду справ у зв'язку з надмірним накопиченням справ у судах, якщо вона оперативно вжила усіх ефективних заходів для виправлення такої ситуації.

Висновки. На підставі викладеного зазначимо, що поняття «розумний строк судового розгляду» $\epsilon$ оцінним поняттям, правовою аксіомою, що виникла на підставі п. 1 ст. 6 Конвенції та рішень Європейського суду з прав людини щодо його тлумачення та становить ідеальну часову модель відправлення правосуддя.

Принцип розумності строків зазначений в тих нормативних актах, які регламентують діяльність органів, наділених повноваженнями правоаналізу. Наразі зроблені вагомі кроки для закріплення права на розумні строки розгляду справи на нормативному рівні, а також для подальшої деталізації його змісту. Проте подальший розвиток та удосконалення механізму захисту такого права має стати пріоритетним напрямом діяльності державних органів України.

Необхідно чітко визначитись з тим, коли починається та закінчується перебіг розумних строків розгляду справи у суді. Відповідно до ст. 6 Конвенції у цивільних, господарських, адміністративних справах перебіг провадження розпочинається з моменту подання позову і закінчується винесенням остаточного рішення у справі. У разі порушення прав особи щодо розгляду іï справи протягом розумного строку відповідальність покладається на державу.

\section{Література}

1. Цивільний процесуальний кодекс України : Закон України від 18.03.2004 р № 1618-IV. URL: https: / / zakon.rada. gov.ua/laws/show/1618-15 (дата звернення 22.10.2019).

2. Конституція України : Закон України від 28.06.1996 p. № 254к/96-BP. URL: https://zakon.rada.gov.ua/laws/card/ 254\%D0\%BA/96-\%D0\%B2\%D1\%80 (дата звернення: 23.10.2019).

3. Про закон «Про статус суддів» : Європейська хартія від 10.07.1998 р. URL: https://zakon.rada.gov.ua/laws/ main/994_236 (дата звернення 23.10.2019).

4. Цивільний процес : навч. посіб. / А.В. Андрушко, Ю.В. Білоусов, Р.О. Стефанчук, О.І. Угриновська та ін. ; за ред. Ю.В. Білоусова. Київ : Прецедент, 2006. 293 с.

5. Курс цивільного процесу : підручник / В.В. Комаров, В.А. Бігун, В.В. Баранкова та ін. ; за ред. В.В. Комарова. Харків : Право, 2011. 1352 с.

6. Дяченко С.В., Сидорчук В.О. Верховенство права: науковий погляд, нормативне закріплення, судова практика. Юридичний бюлетень. Випуск 6. 2018. С. 71-77.

7. Щодо перевищення розумних строків розгляду справ : Лист Верховного Суду України від 25.01.2006 p. № 1-5/45. URL: http://zakon4.rada.gov.ua/ laws/show/v5_45700-06 (дата звернення: 23.10.2019).

8. Про деякі питання дотримання розумних строків розгляду судами цивільних, кримінальних справ і справ про адміністративні правопорушення : рішення пленуму Вищого спеціалізованого суду України з розгляду цивільних та кримінальних справ від 17.10.2014 р. № 11. URL: 


\section{Проблеми цивільного та господарського права}

https://zakon.rada.gov.ua/laws/show/v0011740-14 (дата звернення: 01.11.2019).

9. Про виконавче провадження : Закон України від 02.06.2016 р. Верховна Рада України. URL: https://zakon.rada.gov.ua/laws/show/1404-19 (дата звернення 10.11.2019).

10. Городовенко В.В. Принципи судової влади : монографія. Харків : Право, 2012. 448 с.

11. Узагальнення практики застосування судами загальної юрисдикції першої та апеляційної інстанцій при здійсненні судочинства у кримінальних справах статей 3, 5, 6 Конвенції про захист прав людини і основоположних свобод 1950 року за 2011 - перше півріччя 2012року. Вищий Спеціалізований Суд України. 01.06.2013. URL: https://zakon.rada.gov.ua/laws/show/n0001740-13 (дата звернення: 12.11.2019).
12. Дяченко С.В., Ковтунович Т.О. Неприпустимість зловживання цивільними процесуальними правами як новела цивільного процесу. Юридичний науковий електронний журнал Запорізького національного університету. 2018. Випуск 6. С. 103-106.

Даченко С. В., кандидат юридичних наук, доцент кафедри цивільного права та процесу Університету державної фіскальної служби України

Зборовська Н. О., студентка 4 курсу Навчально-наукового інституту права Університету державної фіскальної служби України 